\title{
Security expertise and international hierarchy: the case of 'The Asia-Pacific Epistemic Community'
}

\author{
Björn Jerdén*
}

Asia Programme Director, Swedish Institute of International Affairs

\begin{abstract}
Many states partially relinquish sovereignty in return for physical protection from a more powerful state. Mainstream theory on international hierarchies holds that such decisions are based on rational assessments of the relative qualities of the political order being offered. Such assessments, however, are bound to be contingent, and as such a reflection of the power to shape understandings of reality. Through a study of the remarkably persistent US-led security hierarchy in East Asia, this article puts forward the concept of the 'epistemic community' as a general explanation of how such understandings are shaped and, hence, why states accept subordinate positions in international hierarchies. The article conceptualises a transnational and multidisciplinary network of experts on international security 'The Asia-Pacific Epistemic Community' - and demonstrates how it operates to convince East Asian policymakers that the current US-led social order is the best choice for maintaining regional 'stability'.
\end{abstract}

\section{Keywords}

Hierarchy; Epistemic Communities; Power; Expertise; The United States; Asia-Pacific

\section{Introduction}

The legitimacy of interstate hierarchical rule in the security sphere is based on a social contract. The subordinate state desires a political order that mitigates the insecurity of the 'state of nature'. The dominant state provides this security, in exchange for which the subordinate state partially relinquishes its sovereignty. ${ }^{1}$ David Lake argues that policymakers in subordinate states base decisions on whether to enter into hierarchical relationships on rational assessments of the relative qualities of the political order being offered to them. ${ }^{2}$ But how are they able to assess how well a particular order meets their needs? Lake's theory cannot help us much here. It simply assumes that state leaders are able to decide on the quality of any proposed order. Appraisals of the relative qualities of an international political order, however, are bound to be contingent and as such an arena for contestation. Analyses of how knowledge is generated lay bare relations in arguably the

* Correspondence to: Björn Jerdén, Swedish Institute of International Affairs, Box 27035, 10251 Stockholm, Sweden. Author's email: bjorn.jerden@ui.se

${ }^{1}$ David A. Lake, Hierarchy in International Relations (Ithaca and London: Cornell University Press, 2009);

David A. Lake, 'Regional hierarchy: Authority and local international order', Review of International Studies, 35 (2009), pp. 35-58.

${ }^{2}$ Lake, Hierarchy in International Relations, pp. 8-9; Lake, 'Regional hierarchy', p. 38. 
most fundamental form of power - the power to shape understandings of reality. ${ }^{3}$ Instead of bracketing the knowledge-producing processes through which policymakers in subordinate states make an assessment of the quality of a political order, we should consider such processes in our explanations of the emergence and continuation of international hierarchies.

This article does this by highlighting the role of an 'epistemic community' of security experts in sustaining the remarkably persistent East Asian support for the region's hierarchical international order led by the 'non-regional' US. The uncertainty of complex international politics has been identified as the key condition for expertise influencing decision-making. ${ }^{4}$ By pointing out natural friends, collective identification with other actors can alleviate the inherent uncertainty in choices about alignment politics. When the sense of common belonging in an international context is thin, however, uncertainty persists. In addition, a relatively peaceful international environment paradoxically increases uncertainty, since it provides decision-makers with few reality checks against which to evaluate the costs and benefits of existing and candidate political orders. Both of these conditions a low level of interstate identification and relative peacefulness - are present in East Asia. Latent regional uncertainty is thus present, which favours the potential impact of security expertise.

When East Asian policymakers articulate their support for the US-led regional hierarchy, they tend to draw heavily on a cause-and-effect claim about the workings of international security: US military supremacy is the indispensable guarantor of regional 'stability'. This 'stability belief', however, is plagued by a number of ambiguities, deficiencies, and uncertainties; the analytical merit of the belief fails to live up to its immense popularity. The article explains the popularity of the belief by focusing on the politics of expertise behind its constitution as an authoritative knowledge claim. I identify the individuals who seem most influential in naturalising the stability belief - a transnational and multidisciplinary network of experts on international security conceptualised as 'The Asia-Pacific Epistemic Community', or TAPEC for short. By internalising the stability belief, providing it with epistemic authority, channelling it into policymaking circles and, in some cases, making policy themselves, TAPEC members help to convince East Asian policymakers that the current US-led social order is the best choice for maintaining national and regional security. Expertise should thus be added to 'charisma, tradition, and social norms ${ }^{5}$ as a potentially critical source of the authority that make states accept subordinate roles in international hierarchies. The epistemic community concept, moreover, is suggested as a general explanation of how expertise on international security is created. The concept is well-suited to capturing contestation and change in the field of security expertise, which are likely to become increasingly important if emerging states attempt to challenge US-led hierarchical regional orders.

China's rise in East Asia might represent the most important challenge to the current US-led international hierarchy. However, none of the steadily expanding scholarship on a possible East Asian 'power shift' from the US to China has thus far recognised the important power resource that

${ }^{3}$ Steven Lukes, Power: A Radical View (2 ${ }^{\text {nd }}$ edn, New York: Palgrave Macmillan, 2005 [orig. pub. 1974]).

${ }^{4}$ Peter M. Haas, 'Introduction: Epistemic communities and international policy coordination', International Organization, 46:1 (1992), pp. 12-16; Mai'a K. Davis Cross, 'Rethinking epistemic communities: Twenty years later', Review of International Studies, 39:1 (2014), pp. 51-3; Christian Bueger, 'From expert communities to epistemic arrangement: Situating expertise in International Relations', in Maximilian Mayer, Mariana Carpes, and Ruth Knoblich (eds), International Relations and the Global Politics of Science and Technology, Volume I (Wiesbaden: Springer VS, 2014), pp. 42-3.

${ }^{5}$ David A. Lake, 'Rightful rules: Authority, order, and the foundations of global governance', International Studies Quarterly, 54:3 (2010), p. 609. 
TAPEC represents, ${ }^{6}$ probably contributing to a tendency to underestimate the resilience of US regional leadership. The extent to which international authority also depends on security expertise in other regions will be a critical area of research for students of international hierarchy.

Sections 2 and 3 present and critically discuss the stability belief. The epistemic community concept and its role in international hierarchy are developed in section 4 and section 5 conceptualises TAPEC. The concluding section sets out the study's contribution.

\section{The epistemic authority of the stability belief}

Around half the world is subject to US-led hierarchy in either the economic or the security sphere. ${ }^{7}$ Lake combines two indicators in an aggregate measure of security hierarchy in dyadic state relationships: (a) the dominant state's troop presence in the subordinate state (more troops equal more hierarchical relations); and (b) the subordinate state's number of independent alliances (fewer alliances equals a higher level of hierarchy). ${ }^{8}$ Security hierarchy is measured on a scale ranging from anarchic relations (no hierarchy) to protectorate relations (maximum hierarchy). ${ }^{9}$ In East Asia, six formal and de facto US allies - Australia, Japan, the Philippines, Singapore, South Korea, and Thailand - have forfeited so much authority over their own security policies that they can be understood as subordinate states. ${ }^{10}$ When justifying their support for the US-led security hierarchy, policymakers in these countries - as well as those in other regional states that welcome the US presence, such as Indonesia, Malaysia, and Vietnam - seem generally to differ from their European counterparts by relying less on appeals to common values or belonging. Instead, they tend to emphasise the knowledge claim that the US provides regional stability. ${ }^{11}$ See, for example, the announcement by Japan's government that its alliance with the US is 'indispensable ... to the peace and stability of the region,12 and the statement by Tony Tan, the minister responsible for Singapore's defence in 1995-2005, that

${ }^{6}$ For example, Amitav Acharya, 'Power shift or paradigm shift? China's rise and Asia's emerging security order', International Studies Quarterly, 58:1 (2013), pp. 1-16; Michael Beckley, 'China's century? Why America's edge will endure', International Security, 36:3 (2011/12), pp. 41-78; Mark Beeson, 'Hegemonic transition in East Asia? The dynamics of Chinese and American power', Review of International Studies, 35:1 (2009), pp. 95-112; Aaron L. Friedberg, 'Ripe for rivalry: Prospects for peace in a multipolar Asia', International Security, 18:3 (1993), pp. 5-33; Evelyn Goh, The Struggle for Order: Hegemony, Hierarchy, and Transition in Post-Cold War East Asia (Oxford: Oxford University Press, 2013); Lake, Hierarchy in International Relations, pp. 181-4; Christopher Layne, 'This time it's real: the end of unipolarity and the Pax Americana', International Studies Quarterly, 56:1 (2012), pp. 202-13; Joseph S. Nye Jr, 'The twenty-first century will not be a "post-American" world', International Studies Quarterly, 56:1 (2012), pp. 215-17; David L. Shambaugh, 'China engages Asia: Reshaping the regional order', International Security, 29:3 (2004/05), pp. 64-99; Hugh White, 'Power shift: Australia's future between Washington and Beijing', Quarterly Essay, 39 (2010), pp. 1-74; William C. Wohlforth, 'How not to evaluate theories', International Studies Quarterly, 56:1 (2012), pp. 219-22; Yan Xuetong, 'The rise of China and its power status', Chinese Journal of International Politics, 1:1 (2006), pp. 5-33.

${ }^{7}$ Lake, Hierarchy in International Relations, pp. 80-2.

${ }^{8}$ Ibid., pp. 68-71.

${ }^{9}$ Ibid., pp. 52-5.

${ }^{10}$ For a conceptual discussion on alliances, see Thomas S. Wilkins, “"Alignment”, not "alliance” - the shifting paradigm of international security cooperation: Toward a conceptual taxonomy of alignment', Review of International Studies, 38:1 (2012), pp. 53-76.

11 This does not mean, however, that references to identity-based factors are totally absent, see, for example, Kai Schulze, 'Facing the "Rise of China": Changes in Japan's Foreign Policy Identity' (PhD thesis, Faculty of Social Sciences, University of Duisburg-Essen, Germany, 2013).

12 Japan Ministry of Foreign Affairs, 'The Japan-US Security Arrangements' (2012), available at: \{http://www. mofa.go.jp/region/n-america/us/security/arrange.html\} accessed 23 June 2015. 
'Singapore believes that the presence of the US military ... contributes to the peace and stability of the region. To that extent, we have facilitated the presence of US military forces. ${ }^{13}$

These official statements are mirrored by academics. For instance, the major scholarly debate on East Asian security in the past two decades has been concerned with how China's growing capabilities will affect its foreign policy. Somewhat simplified, this discussion is divided according to whether China is thought to be a 'status quo' or a 'revisionist' power. Members of these two camps are often at loggerheads, but the vast majority tends to agree that the presence of the US military is necessary for regional stability. ${ }^{14}$ The same broad acceptance of the stability belief is present in many other active debates on East Asian security, such as those on Japan's current foreign and security policy trajectory, ${ }^{15}$ US alliance politics, ${ }^{16}$ and the prospects for regional peace. ${ }^{17}$ Not every participant in these and other influential debates subscribes to the stability belief, but none of the major positions tend to question it seriously. While some accounts suggest alternative factors that facilitate regional stability, few leading scholars openly dispute that the US military presence is a necessary component. The epistemic authority of the belief would be challenged if ideas that explicitly contradict it - such as the claim that great power retrenchment from overseas commitments generally takes place without causing wars - were to become widely accepted. At present, however, similar views hold relatively little sway in the expert discourse on East Asian security.

To illustrate how actors in policy debates draw on the authority of the stability belief in practice, in 2010 the Australian professor and former official Hugh White tried to convince his compatriots that their government 'should try to persuade the US that it would be in everyone's best interests for it to relinquish primacy in Asia'. ${ }^{18}$ The Liberal Party MP Josh Frydenberg retorted, 'Such a major policy reversal would be a disaster for Australia and the region. ... A US that is politically and militarily anchored in the region is best able to influence outcomes that are consistent with the region's longterm stability. ${ }^{, 19}$ Labour Party MP Michael Danby, think tanker Carl Ungerer and adjunct academic Peter Khalil agreed, 'The principal counterweight to Chinese hegemony in our region is the US and its system of alliances ... . It is in Australia's most vital strategic interest that the US presence in our region is not weakened or undermined. ${ }^{20}$ Both previous Prime Minister Kevin Rudd and opposition

${ }^{13}$ Quoted in Robert S. Ross, 'Balance of power politics and the rise of China: Accommodation and balancing in East Asia', Security Studies, 15:3 (2006), p. 391.

${ }^{14}$ For example, Friedberg, 'Ripe for rivalry'; Shambaugh, 'China engages Asia'.

15 For example, Kenneth B. Pyle, Japan Rising: The Resurgence of Japanese Power and Purpose (New York: PublicAffairs, 2009); Richard J. Samuels, Securing Japan: Tokyo’s Grand Strategy and the Future of East Asia (Ithaca and London: Cornell University Press, 2007).

${ }^{16}$ For example, Robert E. Kelly, 'The "pivot" and its problems: American foreign policy in Northeast Asia', The Pacific Review, 27:3 (2014), pp. 479-503; Jae Jeok Park, 'The US-led alliances in the Asia-Pacific: Hedge against potential threats or an undesirable multilateral security order?', The Pacific Review, 24:2 (2011), pp. 137-58.

${ }^{17}$ For example, Thomas Berger, 'Set for stability? Prospects for conflict and cooperation in East Asia', Review of International Studies, 26:3 (2000), pp. 405-28; Evelyn Goh, 'Great powers and hierarchical order in Southeast Asia: Analysing regional security strategies', International Security, 32:3 (2007/08), pp. 113-57.

18 White, 'Power shift', p. 55.

19 Josh Frydenberg, 'Washington is integral to our region', The Australian (21 September 2010), available at: \{http:/www.theaustralian.com.au/news/world/washington-is-integral-to-our-region/story-e6frg6ux-12259269 37881?nk=987ea29957d621bd16b7078abd4f74dd accessed 23 June 2015.

${ }^{20}$ Michael Danby, Carl Ungerer, and Peter Khalil, 'No winners by appeasing China', The Australian (16 September 2010), available at: \{http://www.theaustralian.com.au/opinion/no-winners-by-appeasing-china/ story-e6frg6zo-1225924276179\} accessed 23 June 2015. 
leader Tony Abbot also relied on the stability belief for their rationale when refuting White's argument. ${ }^{21}$ The belief also travels beyond discussions strictly confined to East Asia. For example, in refuting advocacy of US retrenchment from its overseas commitments in general, Stephen Brooks et al. seek to garner support by drawing attention to the fact that among 'regional expertise' on East Asia, 'pessimism regarding the region's prospects without the American pacifier is pronounced'. ${ }^{22}$

The authority of the stability belief becomes even more evident when scholars fall back on it to override the customary implications of general theories of international politics. For balance-ofpower realism, a weaker US presence would seem to enhance regional peace, since a decreased power gap with China would produce more balanced power dispersion between the region's two main poles. Nonetheless, many self-professed balance-of-power theorists deny this supposedly universal logic and argue that a smaller power gap between the US and China would instead threaten peace - a view that is closer to power-transition theory. ${ }^{23}$ This contradiction is also found among policymakers. For instance, the self-professed realist Nagashima Akihisa, a former Vice-Minister of Defense (2009-10) and Prime Minister's Special Adviser on Foreign Affairs and National Security (2011-12) in Japan, justifies his proposal for a strategy that amounts to increased bandwagoning with the US as being based on the maxims of balance-of-power theory. ${ }^{24}$

Robert Keohane and Joseph Nye famously argued that realist theories on the balance of power were of limited use in explaining state interactions under conditions of complex interdependence. ${ }^{25}$ Post-Cold War East Asia witnessed a sharp and steady increase in transboundary economic interactions and multilateral institutional development. Liberal International Relations (IR) theory would expect this to facilitate a redefinition of national interests towards peaceful dispute management, even without a hegemon enforcing compliance. So why does the region need a foreign military power to ensure its peace? John Ikenberry explains this by turning the causal logic of liberal theory on its head - it is not interdependence that takes on the explanatory power as a pacifier, but US military preponderance that guarantees interdependence. ${ }^{26}$ East Asia's interdependence, and thus its peace, would be jeopardised if the US military retrenched. Nye himself has also argued that a withdrawal of US forces would propel East Asia towards 'normal balance-of-power politics' that 'would likely lead to a regional arms race'. ${ }^{27}$

I do not suggest that these particular analyses are influenced by the proper names of the state actors under discussion. Indeed, theoretical fidelity should arguably not be allowed to override one's assessment of the particularities of the empirical case under consideration. It is nonetheless rather

${ }^{21}$ Greg Sheridan, 'US involvement remains central to Asia-Pacific', cogitASIA (24 September 2010), available at: \{http://cogitasia.com/us-involvement-remains-central-to-asia-pacific/\} accessed 23 June 2015.

22 Stephen G. Brooks, G. John Ikenberry, and William C. Wohlforth, 'Don't come home, America: the case against retrenchment', International Security, 37:3 (2012/13), p. 35.

23 Steve Chan, 'An odd thing happened on the way to balancing: East Asian states' reactions to China's rise', International Studies Review, 12:3 (2010), p. 390. See also Detlef Nolte, 'How to compare regional powers: Analytical concepts and research topics', Review of International Studies, 36:4 (2010), p. 888.

${ }^{24}$ Akihisa Nagashima, KatsuBei' to Iu Ryūgi: Gaikō Anzen Hoshō no Riarizumu [The 'Make Use of the US' School: Diplomatic and Security Realism] (Tokyo: Kōdansha, 2013).

25 Robert O. Keohane and Joseph S. Nye, Power and Interdependence: World Politics in Transition (Boston: Little, Brown and Company, 1977).

${ }^{26}$ G. John Ikenberry, 'American hegemony and East Asian order', Australian Journal of International Affairs, $58: 3$ (2004), p. 357.

27 Joseph S. Nye Jr, 'The case for deep engagement', Foreign Affairs, 74:4 (1995), p. 93. 
conspicuous that two of the most widely used factors to explain systemic peace in the IR literature power balancing and interdependence - are practically absent from the debate on East Asia. The peace in this region is instead close to uniformly explained as ultimately depending on the preponderance of US military power.

\section{Ambiguities and deficiencies of the stability belief}

Arguments in favour of the US presence often employ the term 'stability'. As a description of a pattern of interactions in a state system, this term has taken on the same two distinct meanings as Dina Zinnes once associated with 'balance of power'. ${ }^{28}$ Stability can mean the absence of violent conflict, but it can also point to an unchanged status quo. These dissimilar meanings are frequently confused in the debate on East Asia, which results in a tendency to adopt 'unchanged status quo' as both the independent and the dependent variable in the same explanation. For example, Evelyn Goh claims that the US-led order stabilises the region, while at the same time describing the period 1970-90, which as is well known a few years in saw the beginning of a lengthy and more or less uninterrupted decrease in the number of battle-related deaths, ${ }^{29}$ as the least stable period in post-war East Asia. ${ }^{30}$ According to John Ikenberry, moreover, 'the hub-and-spokes system of alliances has provided for remarkable region-wide stability despite the bloody wars inside Korea and Vietnam'. ${ }^{31}$ Since these authors do not equate stability, their explanandum, with 'peace', they must be assumed to take it to mean 'unchanged status quo', which also happens to be their explanans. As an example of an analogous argument using a different vocabulary, Park Jae Jeok argues that 'the hub-and-spoke alliance system serves as a hedge against the possibility that regional multilateralism ... becomes detrimental to the current US-led regional order'. ${ }^{32}$

The repeated usage of stability as a catch-all term harms its conceptual resonance as an analytical tool. It is often unclear what people mean when they argue that the US guarantees East Asia's stability. While the above examples come from scholars, there is little reason to suppose that other security experts - such as journalists, pundits, and policymakers - are better equipped to tell the meanings of stability apart. It would thus not be far-fetched to assume that some experts have come to accept the stability belief as true without formulating a conscious and precise definition of the term. When I talk about the stability belief as a social fact, therefore, I take it to cover also incoherent conceptions. That is not to say that every use of the stability belief is conceptually ambiguous. It is possible to construct a fairly coherent argument that the US facilitates regional peace (or 'stability') by preventing the emergence of latent security dilemmas. It does this in particular by taking the main role in impeding one or more of the 'three vices' of potential regional unrest: Chinese expansionism, Japanese remilitarisation and North Korean nuclear aggression. ${ }^{33}$ This argument could find support

${ }^{28}$ Dina A. Zinnes, 'An analytical study of the balance of power theories', Journal of Peace Research, 4:3 (1967), p. 271.

${ }^{29}$ Timo Kivimäki, 'East Asian relative peace: Does it exist? What is it?', The Pacific Review, 23:4 (2010), p. 506.

${ }^{30}$ Evelyn Goh, 'Hierarchy and the role of the United States in the East Asian security order', International Relations of the Asia-Pacific, 8:3 (2008), pp. 364-66.

${ }^{31}$ Ikenberry, 'American hegemony', p. 364.

32 Park, 'The US-led alliances', p. 147.

33 Berger, 'Set for stability', pp. 406, 425; Brooks et al., 'Don't come home', pp. 35-7; Victor D. Cha, The Impossible State: North Korea, Past and Future (New York: HarperCollins, 2012), p. 215; Friedberg, 'Ripe for rivalry', pp. 31-2; Goh, 'Great powers', p. 153; Pyle, Japan Rising, p. 350; Ross, 'Balance of power politics', p. 395; Samuels, Securing Japan, p. 151; Shambaugh, 'China engages Asia', p. 95. 
in hegemonic stability theory, which posits that unipolar orders are likely to be both peaceful and durable. ${ }^{34}$

The argument seems to have an obvious intuitive advantage: there has been a correlation between the US military presence and relative peace in East Asia since the 1980s. If we go back to the longer Cold War, however, there was in fact a positive correlation between the strength of US hegemony and interstate violence in the region. ${ }^{35}$ Moreover, the extent to which the pacifying effects of transboundary commercial interactions are derivative of and dependent on US hegemony is also unclear. $^{36}$

In addition, if the relative peace in East Asia is hypothesised to be the result of the US-led order, tensions and conflicts must also be considered to be possible features of this order. There are a number of quite plausible arguments that the US presence might inflame the very same developments it is said to prevent. First, China's rapid armament in recent decades - which many regard as the major threat to regional peace - can at least partly be understood as an attempt to decrease the military capability gap between it and the US and its allies. ${ }^{37}$ Second, in sharp contradiction to the argument that the US-Japanese alliance works as a 'cap in the bottle' of Japanese remilitarisation, Washington has for many years persistently and with increasing success urged Japan to enhance its military resources and means. ${ }^{38}$ Third, North Korea's nuclear weapons programme could be seen as a rational pursuit of a credible deterrent against the perceived threat of a US nuclear attack and/or attempt at regime change. ${ }^{39}$ Finally, there is compelling evidence that Japan's alliance with the US has on several occasions served to restrict its ability to qualitatively improve its tense bilateral relationship with China, sometimes as a direct result of US interventions to prevent a loss of control over its ally. ${ }^{40}$

${ }^{34}$ William C. Wohlforth, 'How not to evaluate theories', International Studies Quarterly, 56:1 (2012), p. 220. A similar argument is made in Lake, 'Regional hierarchy'.

${ }^{35}$ Timo Kivimäki, 'Sovereignty, hegemony, and peace in Western Europe and in East Asia', International Relations of the Asia-Pacific, 12:3 (2012), p. 440.

${ }^{36}$ Amitav Acharya and See Seng Tan, 'Betwixt balance and community: America, ASEAN, and the security of Southeast Asia', International Relations of the Asia-Pacific, 6:1 (2006), pp. 37-59; T. J. Pempel, 'More Pax, less Americana in Asia', International Relations of the Asia-Pacific, 10:3 (2010), pp. 465-90.

${ }^{37}$ Avery Goldstein, Rising to the Challenge: China's Grand Strategy and International Security (Stanford: Stanford University Press, 2005), pp. 64-9.

${ }^{38}$ Bjørn E. Mikalsen Grønning, 'Japan's shifting military priorities: Counterbalancing China's rise', Asian Security, 10:1 (2014), pp. 3-9; Ross, 'Balance of power politics', pp. 387-8; Samuels, Securing Japan, pp. 82-4, 94-9. One argument holds that these changes represent an evolutionary approach that does not depart significantly from Japan's self-imposed constraints on its military policy, see Adam P. Liff, 'Japan's defence policy: Abe the Evolutionary', Washington Quarterly, 38:2 (2015), pp. 79-99. Others contend that the meaning of 'peace' in Japanese identity discourse has been altered in such a way to enable, and even necessitate, remilitarisation, see Linus Hagström and Ulv Hanssen, 'War is peace: the rearticulation of "peace" in Japan's China discourse', Review of International Studies, 42:2 (2016), pp. 266-86.

${ }^{39}$ Cha, The Impossible State, pp. 39-40; Selig S. Harrison, Korean Endgame: A Strategy for Reunification and US Disengagement (Princeton and Oxford: Princeton University Press, 2002), pp. 196-200; Joel S. Wit, Daniel B. Poneman, and Robert L. Gallucci, Going Critical: The First North Korean Nuclear Crisis (Washington, DC: Brookings Institution Press, 2004), pp. 36-8.

${ }^{40}$ Victor D. Cha, 'Powerplay: Origins of the US alliance system in Asia', International Security, 34:3 (2009/10), pp. 186-7, 194; Charles A. Kupchan, 'After Pax Americana: Benign power, regional integration, and the sources of a stable multipolarity', International Security, 23:2 (1998), pp. 62-6, 78; Lake, Hierarchy in International Relations, p. 55; Paul O'Shea, 'Overestimating the "power shift": the US role in the failure of the Democratic Party of Japan's “Asia pivot”, Asian Perspective, 38:3 (2014), pp. 435-59. 
Evidence of the stability belief from outside contemporary East Asia is not conclusive. The argument that a hegemonic power is necessary to provide public goods can be challenged on logical grounds, ${ }^{41}$ as well as by pointing to the experience of European integration in the past seventy years. A comparative study of great power decline since 1870 suggests that retrenchment from overseas commitments is unlikely to embroil a declining great power in militarised disputes. ${ }^{42}$ However, to my knowledge there has been no systematic study of how retrenchment affects security competition in the abandoned region. Moreover, to the extent that a rising power is dissatisfied with its international standing, power transition theory ${ }^{43}$ and status theory ${ }^{44}$ would predict deferential retrenchment of other great powers from the rising power's home region to make it more cooperative. As for balance-of-power theory, an empirical test of cross-regional data from the past 2,000 years finds hegemony, rather than balancing, to be the more likely systemic outcome. ${ }^{45}$ If this finding also applies to regional subsystems, balancing dynamics should be expected to be a limited outcome of great power retrenchment. Due to far-reaching normative, trade-related, and military technological changes, furthermore, the incidence of interstate war has fallen sharply over the past two-thirds of a century. Theoretical expectations based on historical comparisons might thus err on the pessimistic side regarding the chances of military conflict. Recent decades contain some events that arguably countervail the stability belief. Brazil's rise in South America has not led to balancing dynamics, despite the absence of a stabilising outside power in the region. The Russian retrenchment from Central and Eastern Europe in the 1990s did not bring much immediate international security competition. In the past decade, Russia has become more aggressive in its near abroad despite the steady expansion of the US-led hierarchy in Europe.

Even without fully accepting all of these objections and counterarguments, together they should make the stability thesis less persuasive than what a majority of observers take it to be. At the very least, it seems extremely difficult to decide with any certainty whether the net effect of the US military presence alleviates, aggravates or does not substantially affect the likelihood of regional conflict. While it is an untested hypothesis that a US withdrawal would not exacerbate security dilemmas, the same is true of the opposite argument. It is telling that some of the most articulate advocates of the proposition ultimately couch their support in terms of preferring 'the devil we know' over an alternative unknown regional security arrangement. ${ }^{46}$ With such intrinsic uncertainty, the question of how East Asian policymakers have come to be so unwavering in their confidence that US hierarchy has a stabilising effect must be said to remain unanswered.

How, then, do policymakers 'learn' that the stability belief is far more credible than alternative ideas? Who 'teaches' them that it is an authoritative knowledge claim? In order to analytically construct this agency, four traits seem to be especially relevant. First, the stability belief is a causal knowledge claim. We are therefore looking for people with recognised expertise on international security,

${ }^{41}$ Duncan Snidal, 'The limits of hegemonic stability theory', International Organization, 39:4 (1985), pp. 579-614.

${ }^{42}$ Paul K. MacDonald and Joseph M. Parent, 'Graceful decline? The surprising success of great power retrenchment', International Security, 35:4 (2011), pp. 7-44.

${ }^{43}$ Ronald L. Tammen et al., Power Transitions: Strategies for the 21st Century (New York: Seven Bridges Press, 2000).

44 T. V. Paul, Deborah Welch Larson, and William C. Wohlforth (eds), Status in World Politics (Cambridge: Cambridge University Press, 2014).

${ }^{45}$ William C. Wohlforth et al., 'Testing Balance-of-Power Theory in world history', European Journal of International Relations, 13:2 (2007), pp. 155-85.

${ }^{46}$ Brooks et al., 'Don't come home', p. 10. 
not for activists primarily driven by principled beliefs. ${ }^{47}$ Second, the experts reproducing the belief are found in many countries. A focus on national fields of expertise in isolation could miss potentially crucial transboundary linkages. ${ }^{48}$ Third, they are active within several occupations. The network thus differs from a transnational 'guild' of professionals. ${ }^{49}$ Finally, most of the experts are not state representatives. We are not therefore seeing a 'government network' in action. ${ }^{50}$ Taking all of these points into consideration, the 'epistemic community' concept seems well suited to capturing the agency involved.

\section{Epistemic communities and international hierarchy}

In international politics, transnational as well as linguistic and politically bounded epistemic communities (epicoms) - 'network[s] of professionals with recognized expertise and competence in a particular domain and an authoritative claim to policy-relevant knowledge within that domain or issue-area, ${ }^{51}$ - arguably play essential roles in the wider policymaking process in many issue areas. Various kinds of experts make up epicoms - not just natural scientists. ${ }^{52}$ The members of an epicom share causal and principled claims, notions to validate their causal claims and a policy enterprise that stems from their common professional competences. ${ }^{53}$ Their causal knowledge claims do not have to be objectively true. What is relevant, for claims about the natural and social world alike, is that community members and their audience believe them to be true. ${ }^{54}$ A group of experts sharing a set of professional attributes is not necessarily an epicom. For example, the nuclear arms control epicom that emerged during the early Cold War did not include all nuclear security experts. Those who advocated either disarmament or military superiority, in particular, were not members since they departed from the community's causal and normative beliefs and its policy project. ${ }^{55}$ Gathering a large share of the experts on an issue should be expected to increase an epicom's potential influence.

The complexity of international politics leads to intrinsic latent uncertainty, which has been identified as the key condition that favours policymakers turning to epicoms for expert solutions. ${ }^{56}$ Unexpected turn of events can further increase uncertainty. ${ }^{57}$ For policymakers considering the costs and benefits of different international political orders, moreover, two additional conditions should be anticipated to augment uncertainty. A first condition is a low level interstate identification. By blurring the perceived boundary between the self and the other, identification distinguishes trusted

${ }^{47}$ Cf. Margaret E. Keck and Kathryn Sikkink, Activists beyond Borders: Advocacy Networks in International Politics (Ithaca and London: Cornell University Press, 1998).

48 Cf. Stefano Guzzini (ed.), The Return of Geopolitics in Europe? Social Mechanisms and Foreign Policy Identity Crises (Cambridge: Cambridge University Press, 2012).

${ }^{49}$ Cf. Didier Bigo, 'Pierre Bourdieu and International Relations: Power of practices, practices of power', International Political Sociology, 5:3 (2011), pp. 225-58.

${ }^{50}$ Cf. Anne-Marie Slaugther, A New World Order (Princeton and Oxford: Princeton University Press, 2004).

${ }^{51}$ Haas, 'Introduction', p. 3.

52 Cross, 'Rethinking epistemic communities', pp. 18-23; Haas, 'Introduction', p. 3.

${ }^{53}$ Haas, 'Introduction', p. 3.

${ }^{54}$ Emanuel Adler, 'The emergence of cooperation: National epistemic communities and the international evolution of the idea of nuclear arms control', International Organization, 46:1 (1992), p. 107; Cross, 'Rethinking epistemic communities', p. 22.

55 Adler, 'The emergence', pp. 111-13, fn. 1.

${ }^{56}$ Cross, 'Rethinking epistemic communities', pp. 151-3.

${ }^{57}$ Emanuel Adler and Peter M. Haas, 'Conclusion: Epistemic communities, world order, and the creation of a reflective research program’, International Organization, 46:1 (1992), p. 380; Haas, 'Introduction’, pp. 12-16. 
friends and thus mitigates uncertainty. ${ }^{58}$ Limited identification, therefore, should be expected to increase uncertainty. A relatively peaceful international environment is a second condition, as it provides few reality checks against which to evaluate knowledge claims about international security. This favours the reliance on experts' counterfactual reasoning based on close familiarity with general theories and empirical conditions. ${ }^{59}$

Epicoms are not just passive providers of expert advice. They proactively use their cognitive authority to influence policymakers' decisions on what constitutes a problem, for example, in the security sphere, by framing issues as requiring management by extraordinary means. ${ }^{60}$ Epicoms are thus not the functional instruments of states, but exercise power independently. Nor is their influence limited to persuading policymakers in a direct causal manner. It also involves producing the background knowledge that underpins social action. ${ }^{61}$ Hence, "the capacity to both "construct" and "naturalize" the social world by imposing certain categories, models and conceptual schemes is a central part of the power of expertise'. ${ }^{62}$ Epicoms are themselves partly constituted by practices of reified background knowledge. Thus, while the approach is agent-focused, epicoms can be said to constitute 'communities of practice'. ${ }^{63}$ Research has highlighted the role of epicoms in achieving policy change, but they can also uphold policy continuity by providing authoritative legitimisation for existing arrangements. An epicom's ideas can turn into orthodoxy if they become institutionalised in national bureaucracies and international organisations. However, internal coherence regarding a community's key beliefs is crucial to maintain its influence. ${ }^{64}$

Much empirical work treats epicoms as highly cohesive groups - with comprehensive interpersonal ties and a strong 'we-feeling'. However, these properties are not implied in Peter Haas's initial concept formation, which sets the course for the research programme. Apart from the main criteria presented above, the complementary definitional features of epicoms all denote common beliefs, values and intentions, rather than interpersonal cohesion or collective identification. ${ }^{65}$ Haas is also clear that the members of an epicom do not need to 'meet regularly in a formal manner'. ${ }^{66}$ The looser requirements of social cohesion were further reinforced when he likened epicoms to Ludwig Fleck's 'thought collectives' and Thomas Kuhn's 'paradigms'. ${ }^{67}$ The agent-centredness of the epicom approach gives rise to a 'boundary problem', of how to isolate members of an expert community

${ }^{58}$ On identification processes, see Alexander Wendt, Social Theory of International Politics (Cambridge: Cambridge University Press, 1999), pp. 229-33.

${ }^{59}$ This logic works similarly to what Emanuel Adler describes as the 'imaginary' science of arms control, see Adler, 'The emergence', p. 107.

${ }^{60}$ For such processes of 'securitization', see Barry Buzan, Ole Wrver, and Jaap de Wilde, Security: A New Framework for Analysis (Boulder, CO: Lynne Rienner Publishers, 1998).

${ }^{61}$ Emanuel Adler and Steven Bernstein, 'Knowledge in power: the epistemic construction of global governance', in Michael Barnett and Raymond Duvall (eds), Power in Global Governance (Cambridge: Cambridge University Press, 2005), pp. 294-318; Christian Bueger, 'From expert communities', pp. 39-54. For a similar argument without reference to epicoms, see Johan Eriksson and Ludvig Norman, 'Political utilisation of scholarly ideas: the "clash of civilisations" vs. "soft power" in US foreign policy', Review of International Studies, 37:1 (2011), pp. 422-3.

${ }^{62}$ Ole J. Sending, 'The formation and transformation of a transnational field', unpublished manuscript (2009).

${ }^{63}$ Emanuel Adler, 'The spread of security communities: Communities of practice, self-restraint, and NATO's post-cold war transformation', European Journal of International Relations, 14:2 (2008), p. 199.

${ }^{64}$ Adler and Haas, 'Conclusion', pp. 384-5.

${ }^{65}$ Haas, 'Introduction', fn. 5.

${ }^{66}$ Ibid., p. 17.

${ }^{67}$ Ibid., fn. 4. 
from other actors in their social context. ${ }^{68}$ Presenting clear evidence for how members meet the community's analytical criteria mitigates this problem.

Analysing the role of epicoms involves a number of tasks: ${ }^{69}$ (i) 'identifying community membership'; (ii) 'determining the community members' principled and causal beliefs'; (iii) 'tracing their activities'; (iv) 'demonstrating their influence on policymakers at various points in time'; (v) 'identifying alternative credible outcomes that were foreclosed as a result of their influence'; and (vi) 'exploring alternative explanations for the actions of decision makers'. Moreover, the literature thus far has arguably been quite weak at analysing epicoms in relation to the knowledge-political contexts in which they exist, including how their influence compares to that of other actors. ${ }^{70}$ Partly as a solution to this problem, epicoms have been situated within field theory. ${ }^{71}$ The field concept is a way to capture patterns of social power struggle. Fields are 'structured spaces that are organized around specific types of capital or combinations of capital'. ${ }^{72}$ 'Capital', moreover, are the material, cultural, social or symbolic power resources that 'become objects of struggle as valued resources'. ${ }^{73}$ The specific fields in which epicoms operate are structured around struggles for the symbolic capital of that which constitutes valid knowledge.

\section{The Asia-Pacific Epistemic Community and US-led security hierarchy in East Asia}

Through an inductive review of knowledge-generating discourses on and practices in East Asian security, I have identified the individuals who seem to be primarily responsible for reproducing the stability belief as an authoritative knowledge claim. These people, who comprise a transnational and multidisciplinary network of socially recognised experts on East Asia's international security, are here conceptualised as 'The Asia-Pacific Epistemic Community'. Community members share the causal knowledge claim that the US military stabilises East Asia, or the stability belief. TAPEC members see the US military as a necessary, although not necessarily sufficient, factor in regional stability. By safeguarding regional stability, the US military presence is perceived to be serving not only the US national interest, but also the interests of the region as a whole. TAPEC's normative claim is that since stability is a good thing, the US should maintain, and preferably strengthen, its security leadership in East Asia for the foreseeable future. TAPEC members thus see the US as an integral part of the 'Asia-Pacific region', and this norm is what gives the community its name here. Flowing from these claims, TAPEC's policy enterprise is to anchor the US military presence in the region. Members promote this objective in various ways: (a) by advising policymakers, either in direct communication or through the policy recommendations in their research outputs; (b) by attempting to influence the general public and other relevant audiences through the mass media and social media; and, in some cases, (c) by making policy themselves. Table 1 summarises the analytical criteria for TAPEC membership. The four criteria are distinct and only individuals who meet all of them can be members. Not all experts on East Asian security are therefore members. Nor are all the experts who accept the validity of the stability belief, unless they also take part in the community's policy project.

${ }^{68}$ Bueger, 'From expert communities', p. 45.

${ }^{69}$ Haas, 'Introduction', p. 34.

${ }^{70}$ Cross, 'Rethinking epistemic communities', pp. 9-11.

71 Sending, 'The formation'.

72 David Swartz, Culture \& Power: The Sociology of Pierre Bourdieu (Chicago: University of Chicago Press, 1997), p. 117.

73 Swartz, Culture \& Power, pp. 73-4. 
Table 1. Analytical criteria for TAPEC membership.

\begin{tabular}{|c|c|}
\hline Criterion & Indicators \\
\hline $\begin{array}{l}\text { 1. Possesses authoritative } \\
\text { knowledge on East Asian security. }\end{array}$ & $\begin{array}{l}\text { One or more of the following: works in a university, } \\
\text { think tank or knowledge-intensive government } \\
\text { office; holds a PhD in a relevant discipline; writes } \\
\text { books, op-eds or editorials about the subject; } \\
\text { interviewed by the media in an expert capacity; } \\
\text { testimony to, or participation in, official } \\
\text { committees, working groups and commissions. }\end{array}$ \\
\hline $\begin{array}{l}\text { 2. Believes that the US military guarantees stability in } \\
\text { East Asia. }\end{array}$ & Written or spoken record of this causal belief. \\
\hline $\begin{array}{l}\text { 3. Believes that stability is a good thing and that the } \\
\text { US should keep its military in East Asia. }\end{array}$ & Written or spoken record of this normative belief. \\
\hline $\begin{array}{l}\text { 4. Works actively to influence policy to maintain or } \\
\text { strengthen the US military presence in East Asia. }\end{array}$ & $\begin{array}{l}\text { Employs means available through own professional } \\
\text { capacity. }\end{array}$ \\
\hline
\end{tabular}

Table 2. Examples of institutions in TAPEC's epistemic infrastructure.

\begin{tabular}{llll}
$\begin{array}{l}\text { Think tank networks, } \\
\text { programmes and } \\
\text { conferences }\end{array}$ & Fellowship programmes & Young leaders' programmes & Publications \\
\hline $\begin{array}{l}\text { Australian American } \\
\text { Leadership Dialogue } \\
\text { (German Marshall Fund } \\
\text { of the United States) }\end{array}$ & $\begin{array}{c}\text { US-Korea Policy Scholars } \\
\text { Programme (Pacific Forum }\end{array}$ & $\begin{array}{l}\text { Kakehashi } \\
\text { Young Leaders }\end{array}$ & The Diplomat \\
CSIS) & & Foundation) & \\
\hline \hline
\end{tabular}

TAPEC members are connected by their authoritative role as experts on the same topic, their shared causal and normative beliefs, and their common policy enterprise. But TAPEC is also a 'community', in the sense that interactions between members constitute a network of crisscrossing interpersonal ties, although not every member has direct contact with all the others. More or less institutionalised social settings provide TAPEC with arenas to share and develop ideas and present them to decisionmakers. This includes universities and academic conferences; think tanks; fellowship and young leaders programmes; academic and policy-related publications and social media; and many of the hundreds of Track II initiatives going on in East Asia and across the Pacific. Many of these sites are organised around objectives or practices that embrace or support TAPEC's policy project, examples of which are shown in Table 2. However, TAPEC members are also active in organised settings whose key missions do not necessarily include anchoring the US military in the region, such as the Council for Security Cooperation in the Asia Pacific (CSCAP) and ASEAN Institute of Strategic and International Studies (ASEAN-ISIS). Few transnational settings of international security expertise in the Asia-Pacific region are built on principles that openly contradict the tenets of TAPEC.

TAPEC members' shared support for US leadership is not ultimately dependent on a normative commitment to the US state, but instead stems from the view that the US military presence is a necessary factor in regional stability. Hence, not all TAPEC members are necessarily 'pro-US'. Nor are they all 'anti-China'; many reject containment policies and advocate encouraging China to take a full part in the international community. For example, Yoon Young-kwan, Professor of International 
Relations at Seoul National University and former Foreign Minister of South Korea (2003-4), advocates reduced US arms sales to Taiwan as part of a grand bargain between the US and China in East Asia, but still favours to maintain the regional military status quo, including US security guarantees to Taiwan. ${ }^{74}$ In general, there is a great deal of variety, complexity, and nuance in many individual TAPEC members' thinking on international affairs, and far from everything they do professionally is related to their belonging to TAPEC. Some of them might even belong to epicoms concerned with other issues as well, such as the 'ASEAN-ologists' described by David Martin Jones and Michael Smith. ${ }^{75}$ This therefore implies that there is much intellectual and political contestation going on within TAPEC - except, of course, when it comes to its core beliefs and policy enterprise. In short, the TAPEC concept is not meant to capture everything meaningful about the social and political relevance of its members' professional activities, just some parts of critical importance to the US-led security hierarchy in East Asia.

TAPEC exists in a field defined by the struggle for what counts as common-sense knowledge about East Asian international security. The field is transnational since the most powerful representations tend to emerge more or less concurrently across different linguistic and political entities. Moreover, a relatively non-discriminatory relation between academic knowledge and other types of expert knowledge characterises the field. This reflects IR - which arguably has the highest concentration of knowledge capital in the field - more broadly. IR stands out among the social sciences by tracing its ideational origins not to universities, but to the world of practitioners. ${ }^{76}$ The blurring in the discipline between theory (IR) and practice (ir) often triggers a 'confusion of observational theories and foreign policy strategies'. ${ }^{77}$ This too helps to explain the strength of the stability belief; the analytical ambiguities probably increase its political appeal, since they open the way for nearly limitless evidence of US-produced 'stability'.

Since TAPEC is a dominant actor in the field, we should expect mechanisms of persuasion and social influence to favour novice experts on East Asian security to conform to the epicom's belief and norm systems. On joining TAPEC, an extensive infrastructure of expertise opens up opportunities for employment, funding, and social recognition. In this way, to paraphrase Benjamin Disraeli, 'The Asia-Pacific is a career.' Table 3 presents a non-exhaustive list of current TAPEC members - the actual membership is much bigger - divided by primary profession and geographical base. ${ }^{78}$ The examples have been picked inductively with the objective to illustrate the breadth of TAPEC's membership. I have included several of the most influential members as well as some junior ones. The emphasis on US individuals reflects the American impact in the field of knowledge production on East Asian international security.

As Table 3 indicates, TAPEC members are well represented in many of the field's national and disciplinary dimensions. This is a key advantage, since the existence of an abundance of actors with the ability to traverse subfield boundaries increases TAPEC's potential impact. Many members would fit into two or more of the occupational categories in Table 3. TAPEC's multidisciplinary nature is thus also present

\footnotetext{
${ }^{74}$ Yoon Young-kwan, 'Will Europe’s past be East Asia’s future?', Politique Étrangère, 1 (2014), pp. 8-9.

75 David Martin Jones and Michael L. R. Smith, 'Is there a Sovietology of South-East Asian studies?', International Affairs, 77:4 (2001), pp. 843-65.

76 Stefano Guzzini, 'The ends of International Relations theory: Stages of reflexivity and modes of theorizing', European Journal of International Relations, 19:3 (2013), pp. 521-41.

77 Ibid., 523-4.

${ }^{78}$ See the appendix for how each individual meets the membership criteria.
} 
Table 3. Non-exhaustive list of TAPEC members.

\begin{tabular}{|c|c|c|c|c|}
\hline $\begin{array}{l}\text { Country/ } \\
\text { region }\end{array}$ & $\begin{array}{l}\text { University } \\
\text { scholar }\end{array}$ & $\begin{array}{l}\text { Think tank } \\
\text { scholar or } \\
\text { analyst }\end{array}$ & $\begin{array}{l}\text { (Former) } \\
\text { Politician or bureaucrat }\end{array}$ & $\begin{array}{l}\text { Journalist, } \\
\text { pundit or } \\
\text { publisher }\end{array}$ \\
\hline US & $\begin{array}{l}\text { Thomas Berger, } \\
\text { Thomas Christensen, } \\
\text { Aaron Friedberg, } \\
\text { John Ikenberry, } \\
\text { David Shambaugh }\end{array}$ & $\begin{array}{l}\text { Michael Auslin, } \\
\text { Patrick Cronin, } \\
\text { Michael Green, } \\
\text { Jeffrey Bader, } \\
\text { Richard Haass }\end{array}$ & $\begin{array}{l}\text { Randy Forbes, } \\
\text { Evan Medeiros, } \\
\text { Joseph Nye, } \\
\text { Ely Ratner, } \\
\text { James Steinberg }\end{array}$ & Peter Ennis \\
\hline Japan & $\begin{array}{c}\text { Kamiya Matake, } \\
\text { Sahashi Ryo, } \\
\text { Sakata Yasuo }\end{array}$ & $\begin{array}{l}\text { Akutsu Hiroyasu, } \\
\text { Michishita Narushige, } \\
\text { Okamoto Yukio }\end{array}$ & $\begin{array}{l}\text { Kitaoka Shinichi, } \\
\text { Nogami Yoshiji, } \\
\text { Tanaka Hitoshi }\end{array}$ & $\begin{array}{l}\text { Funabashi } \\
\text { Yoichi }\end{array}$ \\
\hline Australia & $\begin{array}{l}\text { John Blaxland, } \\
\text { Paul Dibb, } \\
\text { David Envall }\end{array}$ & $\begin{array}{l}\text { Andrew Davies, } \\
\text { Rory Medcalf, } \\
\text { Andrew Shearer }\end{array}$ & $\begin{array}{l}\text { Michael Danby, } \\
\text { Josh Frydenberg, } \\
\text { Kevin Rudd }\end{array}$ & Paul Kelly \\
\hline $\begin{array}{l}\text { Rest of } \\
\text { East Asia }\end{array}$ & $\begin{array}{l}\text { Renato Cruz de Castro, } \\
\text { Park Jae Jeok, } \\
\text { Yoon Young-kwan }\end{array}$ & $\begin{array}{l}\text { Kim Changsu, } \\
\text { Simon Tay, } \\
\text { Woo Jung-yeop }\end{array}$ & $\begin{array}{l}\text { Kim Sung-Han, } \\
\text { Park Jae-Kyung }\end{array}$ & Hong Seok-hyun \\
\hline $\begin{array}{l}\text { Rest of the } \\
\text { world }\end{array}$ & James Manicom & $\begin{array}{l}\text { Xenia Dormandy, } \\
\text { Mike Winnerstig }\end{array}$ & Karl-Heinz Kamp & Geoff Dyer \\
\hline
\end{tabular}

within its individual members. What I call 'scholar-officials' are at the core of TAPEC. ${ }^{79}$ These are security experts engaged in three activities: (a) academic research on international affairs; (b) governmental foreign and security policy work; and (c) the public policy debate in their field of expertise (see Table 4 for examples of the career paths for scholar-officials). Scholar-officials have direct influence over policymaking in their role as government officials, but also wield indirect influence through their participation in public and expert debates. Their knowledge authority is generally not questioned, but instead bolstered by their dual role as academics and practitioners, thanks to the intimate connection between practical knowledge and scholarship in the field. All other things being equal, scholar-officials have a more influential role than TAPEC members with a presence in only one or two subfields. ${ }^{80}$

The field in which TAPEC is active is structured around the struggle to define what counts as common-sense knowledge on East Asian international security. Many of the debates in the field do not directly concern the US regional role. ${ }^{81}$ When this role becomes a topic of contestation, however, TAPEC emerges as an actor. These disagreements also include competing collective actors.

${ }^{79}$ This term is borrowed from a class of civil servants in imperial China (in Chinese shi daifu).

${ }^{80}$ In their innovative work on knowledge production about South East Asian regionalism in the 1990s, David Martin Jones and Michael Smith introduce the concept of the 'scholar-bureaucrat' (see especially Jones and Smith, 'Is there a Sovietology'). Although they do not provide a clear definition of the concept, it seems to denote government-funded researchers (or alternatively, bureaucrats or politicians doing research) for whom academic ideals of objectivity and criticism have more or less completely given way to the propagation of statesponsored ideology. My concept, however, does not imply any intellectual corruption on the part of the scholar-officials (or, for that matter, of TAPEC members in general).

81 The literature on other aspects of knowledge generation about East Asian international relations is too vast to discuss here, but the symposium running over two issues of The Pacific Review in 1994-5 (7:4 and 8:1) deserves a special mention. 
Table 4. Examples of TAPEC scholar-officials' career paths.

\begin{tabular}{lcll}
\hline \hline Joseph Nye & Morimoto Satoshi & Paul Dibb & Evan Medeiros \\
\hline 1964: PhD, Harvard & 1965-76: Japan's Air Self & $\begin{array}{c}\text { 1986-8: Director of the } \\
\text { Australian Defence }\end{array}$ & $\begin{array}{c}\text { 2002: PhD, London School } \\
\text { of Economics }\end{array}$ \\
University & Defence Forces & 2000-9: The RAND \\
1964-93: Academic & 1977-91: Japan's & Intelligence & Corporation \\
positions & Ministry of Foreign & Organization & 2009-13: Director for \\
1993-4: Chairman, US & Affairs & 1988-91: Deputy & China, Taiwan, Mongolia \\
National Intelligence & 1992-4: Nomura & Secretary in the & Affairs, US National \\
Council & Research & Australian & Security Council \\
1994-5: US Assistant & 1995-2010: Academic & Department of & 2013-15: Senior Director \\
Secretary of Defence for & positions & Defence & for Asian Affairs, US \\
International Security & 2009: Special Adviser to & 1991: Academic & National Security Council \\
Affairs & the Minister of Defence & positions (since 2004 & Nation \\
1995-: Academic positions & 2012: Minister of & emeritus) & 2015-: Eurasia Group \\
(since 2004 emeritus) & Defence & & \\
\hline \hline
\end{tabular}

The field contains at least one other fully-fledged transnational epicom of security experts with a credo that clashes with the stability belief, here identified as the 'Anti-Hegemonic Epistemic Community' (AHEC). AHEC members share a causal knowledge claim that the US military presence in East Asia disrupts the ability to establish more enduring peaceful relations between regional actors; a set of social scientific notions to validate this claim; a principled belief that the US should withdraw, significantly decrease, or at least not enhance its force presence; and a policy enterprise to convince the public and policymakers of this objective. Prominent members include the historian, John Dower, the political scientists, Gavan McCormack and Karel van Wolferen, the former Japanese diplomat, Magosaki Ukeru, and, until his death in March 2015, the former Prime Minister of Australia, Malcolm Fraser. Although these ideas have certain traction among strands of East Asian public opinion, ${ }^{82}$ AHEC's influence on the expert discourse on international security is fairly circumscribed. The causal knowledge claim is not thoroughly institutionalised in any regional foreign policy bureaucracy, with the possible exception of North Korea - and that is probably completely unrelated to AHEC's possible influence. Chinese government representatives have a mixed record of professing its support for the US military presence in East Asia, ${ }^{83}$ on the one hand, and pointing out the negative consequences of its presence, ${ }^{84}$ on the other.

Leaving aside the question of the possible analytical weaknesses in the knowledge claim, we can identify two factors that limit the success of AHEC. First, although AHEC has established a sphere of discussion built around journals such as Critical Asian Studies and Asia-Pacific Journal: Japan Focus, this has not developed into a transnational infrastructure of expertise, complete with think tank networks, regular conferences, fellowships, young leaders' programmes, and so on. This limits the opportunities for policymakers to come into contact with AHEC's ideas and, if they do, to perceive them as authoritative. It also makes it difficult to make a career within AHEC, which probably reduces its supply of talented and ambitious experts. Second, AHEC members tend to combine the

${ }^{82}$ Andrew Yeo, Activists, Alliances, and Anti-US Base Protests (Cambridge: Cambridge University Press, 2011).

${ }^{83}$ See, for example, Shambaugh, 'China engages Asia', p. 91.

${ }^{84}$ See, for example, Xi Jinping, 'Statement by H. E. Mr. Xi Jinping, President of the People's Republic of China. Conference on Interaction and Confidence Building Measures in Asia (CICA)' (2014), available at: \{http:// www.s-cica.org/page.php?page_id=711\&lang=1\} accessed 23 June 2015. 
above claims with additional normative criticism of subordinate states' decisions to relinquish policy authority to the US. ${ }^{85}$ In this sense, AHEC is a mixture of an epicom and an 'advocacy network' ${ }^{86}$ This normative critique, however, has been largely ineffectual against the knowledge claim that US hierarchy is necessary to secure systemic stability. Confident in the validity of the stability belief, two TAPEC members, for example, have dismissed Australian anti-base campaigners as, "highly ideological, pathologically anti-American' ${ }^{87}$

The field also encompasses a number of more local knowledge actors with claims and practices that tend to conflict with TAPEC. One prominent example is conceptualised here as the 'Peaceful Rise Epistemic Community' (PREC). With a membership that encompasses large parts of the Chinese security intelligentsia, as well as some foreign experts, PREC members share the causal belief that China's foreign policy is inherently peaceful; the normative belief that worrying about the effects of growing Chinese capabilities is irrational and based on the malicious or ignorant "China threat theory', or on out-dated 'Cold War thinking'; and a policy enterprise to prevent foreign containment of China's rise to undisputed great power status. PREC's core beliefs are ultimately validated by a cultural exceptionalism that identifies China as a new type of benevolent great power, ${ }^{88}$ and by the allegedly infallible scientific analytical methodology of the Chinese Communist Party's political theory. ${ }^{89}$ These notions do not contradict US military supremacy per se, and the majority of Chinese IR scholars arguably adhere to the stability belief. ${ }^{90}$ PREC members, nonetheless, regularly dispute TAPEC members' common claim that US forces are necessary to deter Chinese expansionism. Language hurdles, dissimilarities in academic culture and a general failure to provide convincing analytical backing for China's inherent peacefulness are all likely to help explain PREC's limited success in influencing international debates. It is also important to point out that not all Chinese security experts are PREC members. For example, Yan Xuetong, one of China's leading IR scholars, implicitly dismisses the validity of PREC's causal knowledge claim by arguing, among other things, that 'there will be few win-win situations in China's ascent to a superpower'. ${ }^{91}$

\section{TAPEC and Japan's strategic vacillation, 2009-10}

The following episode illustrates how TAPEC has taken on a key role in reproducing the stability belief as an authoritative knowledge claim, and how this influences subordinates in East Asia to adopt a positive view of US security hierarchy relative to alternative security arrangements. The section thus provides further elaboration of the arguments presented earlier in the text.

${ }^{85}$ See, for example, Gavan McCormack, Client State: Japan in the American Embrace (London and New York: Verso, 2007); Kyoji Yanagisawa et al., Datsu Domei Jidai: Sōri Kantei de Iraku no Jieitai o Tōkatsu shita Otoko no Jishō to Taiwa [The Age of Leaving the Alliance: Dialogue and Self-Examination of the Man at the Prime Minister's Office who Oversaw the Iraq Self-Defence Forces] (Kyoto: Kamogawa Shuppan, 2011).

${ }^{86}$ Cf. Keck and Sikkink, Activists beyond Borders.

${ }^{87}$ Jack McCaffrie and Chris Rahman, 'The US strategic relationship with Australia', in Carnes Lord and Andrew S. Erickson (eds), Rebalancing US Forces: Basing and Forward Presence in the Asia-Pacific (Annapolis: Naval Institute Press, 2014), p. 89 f.

${ }^{88}$ On Chinese exceptionalism, see Zhang Feng, 'The rise of Chinese exceptionalism in international relations', European Journal of International Relations, 19:2 (2013), pp. 310-12.

${ }^{89}$ On CCP theory, see Timothy R. Heath, 'What does China want? Discerning the PRC's national strategy', Asian Security, 8:1 (2012), p. 55.

${ }^{90}$ Song Xinning, professor at Renmin University and a prominent figure in the development of IR in China, made this assessment in conversation with the author in Warsaw, September 2013.

91 Yan, 'The rise', p. 14. 
However, it should be pointed out that this is not a structured and focused case study that beyond doubt substantiates the causal significance of TAPEC. I shall return to the issue of limitations and further research in the concluding section.

The Obama Administration initially faced a serious problem with its East Asia policy. In the early autumn of 2009, the newly elected Democratic Party of Japan (DPJ) government, led by Prime Minister Hatoyama Yukio, declared its intention to implement several important changes in Japan's foreign and security policy. Three such changes deserve special attention: (a) making the Japan-US relationship more equal, while at the same time striking a more even balance between Japan's relationships with the US and China; (b) working towards establishing an East Asian community built on functional integration, seemingly without US participation; and (c) revoking a previously concluded agreement with the US in order to move the contentious Futenma Marine Corps base out of Okinawa prefecture, and possibly out of Japan altogether. ${ }^{92}$ If successfully executed, these changes could have decreased the US force presence in Japan and opened the way for Tokyo to enter into alliance-style relationships independently of Washington. It could also have served to spur other countries in the region to reconsider their dependence on the US military. In other words, Japan arguably the key US regional ally - was planning a strategic reorientation that might have reduced the level of US security hierarchy in East Asia.

From the outset, the Japanese government's new strategy was heavily criticised by different camps both inside and outside Japan. ${ }^{93}$ Much of this criticism drew on the authority of the stability belief: the DPJ government was accused of not appreciating that any cutbacks in the US military presence would jeopardise the security situation in Japan and the region. Resistance from the US government, conservative Japanese news media and the DPJ's main political rival, the Liberal Democratic Party (LDP), was to be expected. Slightly more surprising, perhaps, was the consistent behind-the-scenes opposition from high-ranking officials within Japan's own foreign ministry. Thanks to the massive leak of US diplomatic cables by the WikiLeaks organisation in 2010, we have insights into the diplomats' resistance to all three of the policy changes outlined above, or at least interpretations of their statements of resistance by the US diplomats who wrote the cables.

Saiki Akitaka, Director General for Asian and Oceanic Affairs, confessed to Kurt Campbell, the US Assistant Secretary of State for East Asian and Pacific Affairs, on 17 September 2009 that he could not understand the Hatoyama Administration's call for a more equal relationship since the Japanese-US relationship was 'already equal'. ${ }^{44}$ In another meeting with Campbell on 12 October, Saiki stressed that Hatoyama's comments that Japan had been excessively dependent on the US were 'inappropriate' and had 'surprised' the ministry. Saiki also acknowledged that his boss, Foreign Minister Okada Katsuya, had been 'obstinate' about not including the US in the blueprint for an East

92 Il Hyun Cho and Seo-Hyun Park, 'Domestic legitimacy politics and varieties of regionalism in East Asia', Review of International Studies, 40:3 (2014), pp. 599-600; Christopher W. Hughes, 'The Democratic Party of Japan's new (but failing) grand security strategy: From "reluctant realism" to "resentful realism"?, Journal of Japanese Studies, 38:1 (2012), pp. 109-40; O'Shea, 'Overestimating the "power shift"'.

${ }^{93}$ Axel Berkofsky and Linus Hagström, 'Futenma and the Mobilization of Bias: an Alternative Perspective on the Japan-US Alliance', ISPI Working Paper, no. 38 (2010); Hughes, 'The Democratic Party'; O'Shea, 'Overestimating the "power shift"'.

${ }^{94}$ WikiLeaks, 'Cable 09TOKYO2197: EAP Assistant Secretary Kurt Campbell's Meeting with MOFA DG Akitaka Saiki' (2009), available at: \{http://www.wikileaks.org/cable/2009/09/09TOKYO2197.html\} accessed 23 June 2015. 
Asian community. As a 'MOFA bureaucrat', however, Saiki expressed his view that 'it was unthinkable to exclude the United States'. ${ }^{95}$ On 12 November, Japan's Ambassador to the US, Fujisaki Ichirō, offered friendly advice to his US counterpart on how President Obama could put pressure on Hatoyama in their meeting the next day: 'the President should tactfully make the point that an expeditious resolution of the Futenma Replacement Facility ... issue is a problem for Prime Minister Hatoyama and Japan to resolve (not the United States), ${ }^{96}$

Why did senior Japanese diplomats undermine their elected leaders? Self-interest is likely to have played a role - the DPJ had promised voters that it would wrestle decision-making power from the hands of bureaucrats to elected politicians. ${ }^{97}$ Nonetheless, a strong conviction in the truth of the stability belief and apprehension that the DPJ government did not appreciate its importance were also factors in the stance taken by ministry officials. When it came to 'the details and rationale behind US-Japan security policy', Vice-Minister for Foreign Affairs Yabunaka Mitoji told US Ambassador John Roos on 21 December, 'some DPJ leaders' faced a 'sometimes steep learning curve'. According to Yabunaka, it was therefore advisable to push for informal talks instead of a formal bilateral dialogue in order to avoid 'the Hatoyama Administration and/or ruling coalition political leaders [taking] positions based on incomplete or erroneous understandings of alliance issues and options'. At the same time, Yabunaka expressed some confidence about 'efforts to educate' those 'television commentators and politicians' who lacked a 'strong a grasp of security issues'. ${ }^{98}$ Saiki, too, in his September talks with Campbell, called the Hatoyama Administration's strategy of challenging the US 'stupid', but noted that 'they will learn'. 99

These Japanese diplomats are all TAPEC members; both Fujisaki and Yabunaka have taken up academic and think tank positions since their retirement. Influential US TAPEC scholarofficials, such as Richard Armitage, Victor Cha, Michael Green, and Joseph Nye, were also active early on in relying on the axiomatic knowledge authority of the stability claim to discredit the DPJ government's strategic reorientation. ${ }^{100}$ Frequent contacts between TAPEC members in different subfields continued throughout the tumultuous period. In January 2010, for example, the Japanese Embassy helped to sponsor the Sixteenth Japan-US Security Seminar in Washington, DC. This biannual conference is one of the more high-profile regular gatherings between Japanese and US 'alliance managers' - a tight community of bureaucrats, politicians, think tankers, and scholar-officials, the vast majority of whom belong to TAPEC. In a written rundown of one of the closed sessions, Brad Glosserman set out the mainstream sentiment among TAPEC members at the time:

Many see the frictions in the Japan-US alliance as stemming from the failure of the new Japanese government to appreciate the complexities of issues in the security arena; as it

${ }^{95}$ WikiLeaks, 'Cable 09TOKYO2377: A/S Campbell, GOJ Officials Discuss PM Hatoyama’s Comments on US/ China/South Korea' (2009), available at: \{http://www.wikileaks.org/cable/2009/10/09TOKYO2377.html\} accessed 23 June 2015.

${ }^{96}$ WikiLeaks, 'Cable 09TOKYO2618: Ambassador Discusses President's Visit with Japanese Ambassador Fujisaki' (2009), available at: \{http://www.wikileaks.org/cable/2009/11/09TOKYO2618.html\} accessed 23 June 2015.

${ }^{97}$ See Hughes, 'The Democratic Party', pp. 136-7.

${ }^{98}$ WikiLeaks, 'Cable 09TOKYO2946: Ambassador's December 21 Lunch Meeting with Vice Foreign Minister Yabunaka' (2009), available at: \{http://www.wikileaks.org/cable/2009/12/09TOKYO2946.html\} accessed 23 June 2015.

${ }^{99}$ WikiLeaks, 'Cable 09TOKYO2197'.

100 O'Shea', 'Overestimating the "power shift”, pp. 442-4, 449-53. 
becomes more informed of those nuances, foreign and security policies will revert to the norm of its Liberal Democratic Party (LDP) predecessors. ${ }^{101}$

The need to educate misinformed politicians about the validity of the stability belief was a reoccurring theme at the conference, as can be seen in Glosserman's summary of Shelia Smith's presentation:

A country that lacks a tradition of alternation of governments is unlikely to have an informed opposition. There should be outreach to a wider group of individuals. Information needs to [be] better distributed. There needs to be a better understanding of the role the alliance plays in securing Japan and the role of the Marines in accomplishing that objective. Japan's opposition - whoever it is - needs to learn to think in terms of the national interest[.] $]^{102}$

Such activities enjoyed significant success in shaping perceptions of the Japanese Administration's strategic shift, just as expected by many TAPEC members. This helped to make Hatoyama's position increasingly untenable. On 4 May 2010, less than eight months after the DPJ assumed power, Hatoyama told reporters that at the time of the election of 2009, which brought his party to power, 'I did not think that the Marine Corps was necessarily needed in Okinawa as a deterrent.' However, 'the more he studied' he eventually came to 'realize' that their presence served deterrence purposes. ${ }^{103}$ That is to say, Hatoyama did an about-face and - in the words of the TAPEC members referred to above - declared that he had been 'educated' about the validity of the stability belief. Hatoyama resigned as prime minister less than one month later. This public acknowledgement of the stability belief signified Japan's decision to abandon its proposed strategic reorientation and instead throw its full support behind a regional security order based around a bolstered US hierarchy.

The Japanese government lacked fixed preferences about which international security order was best able to meet its professed interests. Instead, it vacillated between two different orders. It eventually endorsed the order championed by the US, thus enforcing US security hierarchy, but this could not have been predicted based only on the analyst's assessment of the objective security-endowing qualities of these orders. The episode highlights how entrenched knowledge structures in bureaucracies can contribute to path dependency in policymaking. At the same time, it also shows that active reinforcement is necessary to keep these structures in place. The stability belief was dominant in Japan in 2009, but it was not dogma. The process that led to the downfall of the Hatoyama Administration was also a struggle over what counts as valid knowledge on international security. The Hatoyama Administration has frequently been accused of incompetency in its conduct of foreign policy. While I do not dispute that its executive skills were far from optimal, my point is that allegations of ineptitude at least partly stems from the Administration's initial refusal fully to accept the alleged wisdom of the stability belief.

\section{Summary and discussion}

Policymakers partly agree to have their states take on subordinate positions in hierarchical relationships due to their cost-benefit calculations. ${ }^{104}$ But on what knowledge of costs and benefits are

${ }^{101}$ Brad Glosserman, 'Celebrate or separate? The Japan-US security treaty at 50: a conference report', Pacific Forum CSIS Issues \& Insights, 10:15 (2010), p. 4, available at: [http://csis.org/files/publication/issuesinsights_v10n15.pdf\} accessed 23 June 2015.

102 Ibid., p. 5.

${ }^{103}$ Nihon Keizai Shimbun, 'Shushō: Kaiheitai, shōshiryoku to omotte inakatta' [Prime Minister: I did not think that the marines provided deterrence], available at: \{http://www.nikkei.com/article/DGXNASFS0401A U0A500C1MM8000/\} accessed 23 June 2015.

${ }^{104}$ Lake, Hierarchy in International Relations, pp. 8-9. 
these calculations based? This article suggests epicoms as a general explanation of how this knowledge is produced. In this way, it highlights the crucial role of expertise in the emergence and sustainability of hierarchies in world politics. ${ }^{105}$ I thus follow up on calls to identify the different sources of dominant states' legitimacy in hierarchical relationships; ${ }^{106}$ the agents and networks behind the ideational structures underpinning global governance; ${ }^{107}$ as well as the linkages between the different hierarchical logics of functional bargains, on the one hand, and knowledge structures, on the other. ${ }^{108}$

By analysing the generation and political mobilisation of security knowledge, the study sheds light on a crucial but so far neglected aspect of the remarkably persistent US security hierarchy in East Asia. I have attempted to demonstrate that the stability belief - the ubiquitous idea that US military predominance ensures regional stability - is critical in convincing East Asian policy elites that the US-led order is legitimate. Since the analytical merit of this belief does not live up to what one would expect from its close to universal traction, I have moreover argued that we must study the knowledge politics behind the ongoing constitution of the belief. A transnational and multidisciplinary network of experts on international security - TAPEC - is found to be primarily responsible for reproducing the belief as an authoritative knowledge claim. TAPEC therefore makes US security hierarchy in East Asia possible. It can be understood as a key source of US 'soft power'. ${ }^{109}$ TAPEC helps to make US hierarchy attractive in the eyes of East Asian policymakers.

Through TAPEC, the legitimacy of US hierarchy in East Asia to a certain extent relies on a transnational community decoupled from absolute state control. ${ }^{110}$ This might seem like a precarious foundation for international leadership. It is however doubtful whether the US would be able to rely solely on military might, economic prowess or, for that matter, cultural attractiveness or valuesbased transnational collective identities to secure its dominant military presence in East Asia. TAPEC might therefore be a necessary condition for the continuation of US security hierarchy. The politics of expertise thus becomes an essential indicator when theorising about the possibilities of a 'power shift' in East Asia. The burgeoning literature on the topic, however, has so far more or less completely overlooked the mechanisms by which knowledge on international security is created and politically employed. ${ }^{111}$

Such neglect might contribute to a tendency to underestimate the resilience of US hierarchy and, conversely, to overestimate China's ability to translate economic and military capabilities into real policy effects and the creation of a sphere of influence at the expense of the US. David Shambaugh,

105 On expertise as a source of international legitimacy, see Andrew Hurrell, 'Legitimacy and the use of force: Can the circle be squared?', Review of International Studies, 31 (2005), pp. 15-32. For a critical view, see David P. Rapkin and Dan Braaten, 'Conceptualising hegemonic stability', Review of International Studies, 35:5 (2009), p. 125.

106 David A. Lake, 'Rightful rules: Authority, order, and the foundations of global governance', International Studies Quarterly, 54:3 (2010), p. 609.

107 Thomas G. Weiss and Rorden Wilkinson, 'Rethinking global governance? Complexity, authority, power, change', International Studies Quarterly, 58:1 (2014), p. 211.

108 Janice Bially Mattern and Ayşe Zarakol, 'Hierarchies in world politics', International Organization, 70:3 (2016), p. 623-54.

109 On soft power, see Nye, 'The twenty-first century', p. 216.

${ }^{110}$ Cf. Bigo, 'Pierre Bourdieu', pp. 253-4.

111 For example, Acharya, 'Power shift'; Beckley, 'China’s century'; Beeson, 'Hegemonic transition'; Friedberg, 'Ripe for rivalry'; Lake, Hierarchy in International Relations, pp. 181-4; Goh, The Struggle for Order; Layne, 'This time'; Nye, 'The twenty-first century'; Shambaugh, 'China engages Asia'; White, 'Power shift'; Wohlforth, 'How not'; Yan, 'The rise'. 
for example, predicted about a decade ago that, 'The nascent tendency of some Asian states to bandwagon with Beijing is likely to become more manifest over time'; ${ }^{112}$ and Yan Xuetong agreed that: 'China's endeavours in East Asian regionalization will effectively enhance its ability for political mobilization over the next 10 years. ${ }^{113}$ A few years later, Mark Beeson wrote in a similar vein, '... China has begun to enunciate an alternative vision of development and international order that may help to consolidate its position at the centre of an emergent regional system at the expense of the US'. ${ }^{114}$ We have instead seen the opposite. Identifiable Chinese influence in many issue areas remains limited or has declined, ${ }^{115}$ while the US-led security hierarchy, as seen in the regional embrace of the US policy to 'pivot' to Asia, has grown stronger.

Measuring economic and military capabilities is clearly not enough in order to understand this turn of events. Attention on the social production of legitimacy enables more accurate explanations and predictions of the dynamics of international hierarchies. While this productively has been done in the East Asian context, ${ }^{116}$ the important role of expert knowledge has so far been left largely untouched. I do not claim that TAPEC is the sole reason why East Asian elites perceive the US security hierarchy as legitimate. While I hypothesise that security expertise becomes more important when - as in East Asia - interstate identification is thinner and military conflict is rarer, more comparative research is needed on expertise relative to other sources of international authority. Moreover, the TAPEC case requires further inquiry in order to determine more exactly the causal mechanisms and scale of its impact. This study has concentrated on conceptualising the community and the field in which it is active, as well as criticising rival explanations for the strength of the stability belief. Future research should compare TAPEC's influence in different national contexts in East Asia, and look into contrasts with other regions with variance in the presence of extensive transnational epicoms. Process tracing, ethnography, and structured and focused case studies are also needed to elaborate the mechanisms of TAPEC's influence. Studies of the origins of TAPEC, as well as its role in critical junctures, such as after the end of the Cold War, would also be valuable.

To conclude, since IR scholars often take part in creating the very phenomena they are studying, a reflexive attitude towards this connection is imperative. ${ }^{117}$ While the epicom concept was originally developed by IR scholars to study natural scientists, this study turns the concept around by directing the searchlight at an epicom in which IR scholars themselves play prominent roles. Some in the IR profession have called on their peers to do more policy relevant theoretical work, ${ }^{118}$ to disseminate their ideas to policymakers, ${ }^{119}$ and to take on government positions. ${ }^{120}$ Since the

112 Shambaugh, 'China engages Asia', p. 99.

113 Yan, 'The rise', p. 29.

114 Beeson, 'Hegemonic transition', p. 100.

${ }^{115}$ Evelyn Goh, 'The modes of China's influence: Cases from Southeast Asia', Asian Survey, 54:5 (2014), pp. 825-48; Karl Gustafsson, 'Is China's discursive power increasing? The case of the "power of the past" in Sino-Japanese relations', Asian Perspective, 38:3 (2014), pp. 411-33; David L. Shambaugh, China Goes Global: The Partial Power (Oxford: Oxford University Press, 2013).

${ }^{116}$ Goh, The Struggle for Order.

${ }^{117}$ Steve Smith, 'Singing our world into existence: International Relations theory and September 11', International Studies Quarterly, 48:3 (2004), pp. 499-515. See also Bueger, 'From epistemic communities', pp. 51-2.

${ }^{118}$ David A. Lake, "Why "isms" are evil: Theory, epistemology, and academic sects as impediments to understanding and progress', International Studies Quarterly, 55:2 (2011), pp. 465-80.

119 Johan Eriksson and Bengt Sundelius, 'Molding minds that form policy: How to make research useful', International Studies Perspectives, 6:1 (2005), pp. 51-71.

${ }^{120}$ Joseph S. Nye Jr, 'Scholars on the sidelines', Washington Post (13 April 2009). 
scholarly members of TAPEC embrace such advice to a greater extent than their colleagues in many other subfields of IR, the article can be read as a case study of the opportunities and pitfalls, for scholarship as well as for policy, of proactive academic involvement in the wider policymaking process.

\section{Acknowledgements}

For their helpful comments on earlier (in some cases, much earlier) versions of this article, the author would like to thank the editors and reviewers of Review of International Studies, Hans Agné, Idris Ahmedi, Andrew Bennett, Henrik Berglund, Stefan Borg, Niklas Bremberg, Steve Chan, Félix Grenier, Karl Gustafsson, Stefano Guzzini, Linus Hagström, Jan Hallenberg, Ulv Hanssen, Joakim Kreutz, Niklas Nilsson, Tarek Oraby, Gustav Ramström, J. Patrick Rhamey, Thomas Risse, Jeff Roquen, Jonas Tallberg, Jan Teorell, and Stein Tønnesson.

\section{Supplementary material}

To view supplementary material for this article, please visit https://doi.org/10.1017/S02602105 16000437

\section{Biographical information}

Björn Jerdén is Asia Programme Director at the Swedish Institute of International Affairs. His research has previously appeared in Pacific Affairs, Asian Perspective, Journal of East Asian Studies, and The Chinese Journal of International Politics. 